\title{
症例
}

術前CTにて“whirl sign”を呈した成人原発性小腸軸捻転症の 1 例

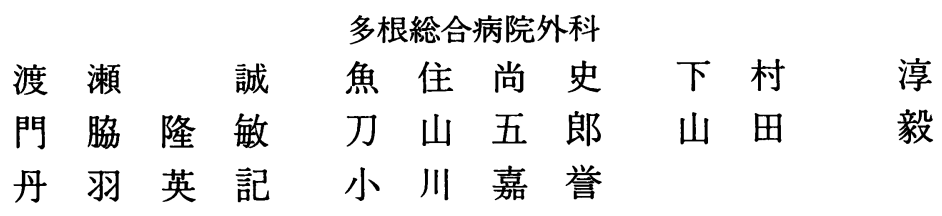

\section{A Case of Adult Primary Small Bowel Volvulus Preoperatively Diagnosed by "Whirl Sign" on Computed Tomography}

\author{
Makoto WATASE, Naofumi UOZUMI, Atsushi SHIMOMURA, \\ Takatoshi KADOWAKI, Goro TACHIYAMA, Tsuyoshi YAMADA, \\ Hideki NIWA and Yoshitaka OGAWA \\ Department of Surgery, Tane General Hospital
}

症例は17歳女性で心窝部鈍痛, 嘔気を主訴に来院した。術前CTでは腸間膜動脈周囲を小腸が渦巻き状に巻き込 む “whirl sign”を認め緊急手術を施行した。200 cmの小腸が上腸間膜動脈を中心に 360 度捻転し壊死に陥ってい た。先天的な腸回転異常症や既往の手術による癒着などのないことより原発性小腸軸捻転症と診断した。

索引用語：成人原発性小腸軸捻転症（adult primary small bowel volvulus), CT (computed tomography), whirl sign

\section{はじめに}

原発性小腸軸捻転症は，先天的な腸回転異常症 や既往の手術による癒着などのない小腸の軸捻転 を示しており1)，本邦においては小児では約40例 の報告が認められるが2成人ではさらに少ない。 原発性小腸軸捻転症の認識は未だ浅く, 診断の遅 れが致命的な結果を招くこともしばしばであ る3)。今回われわれは, CT上典型的な“whirl sign” を認め4)，手術的に救命し之た成人原発性小腸軸 捻転症の 1 例を経験したので報告する。

\section{症例}

症 例: 17歳, 女性。

主 訴: 心窩部鈍痛, 食後の嘔気。
既往歴：特記すべきことなし。

家族歴：特記すべきことなし。

現病歴：2000年 5 月 6 日夕食後，急に心窩部鈍 痛と嘔気を認めたため当院を受診した。嘔吐およ び下㢉は認められなかった。

入院時現症：体格中等度, 血圧 $130 / 68 \mathrm{mmHg}$, 脈拍 $90 /$ 分, 体温 $36.4^{\circ} \mathrm{C}$, 結膜に黄疸貧血なく, 胸 部聴打診上異常なかった。腹部は心窩部に鈍痛を 認めるも軟で, 筋性防御などの腹膜刺激症状は認 めなかった。血液検查では, 白血球数 $10,900 /$ $\mathrm{mm}^{3}, \mathrm{CPK} 170 \mathrm{IU} / \mathrm{L}$ 軽度高值を示したがその他 には異常を認めなかった。腹部単純X線検查 (Fig. 1 ）に異常は認められなかった。急性胃腸炎と診 断し入院となった。

入院後経過：入院後痛みは次第に上腹部から下 


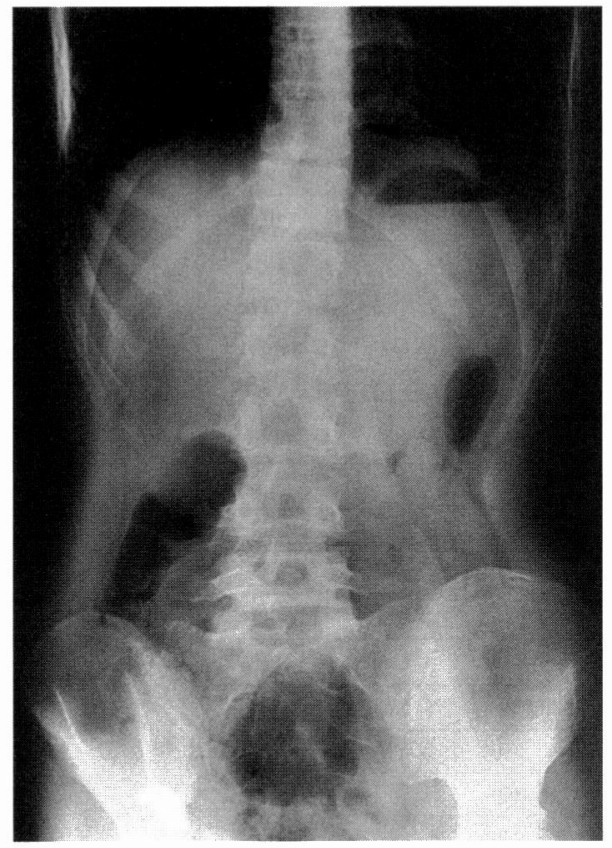

Fig. 1 Abdominal $X$-ray on admission shows an unremarkable bowel gas pattern.

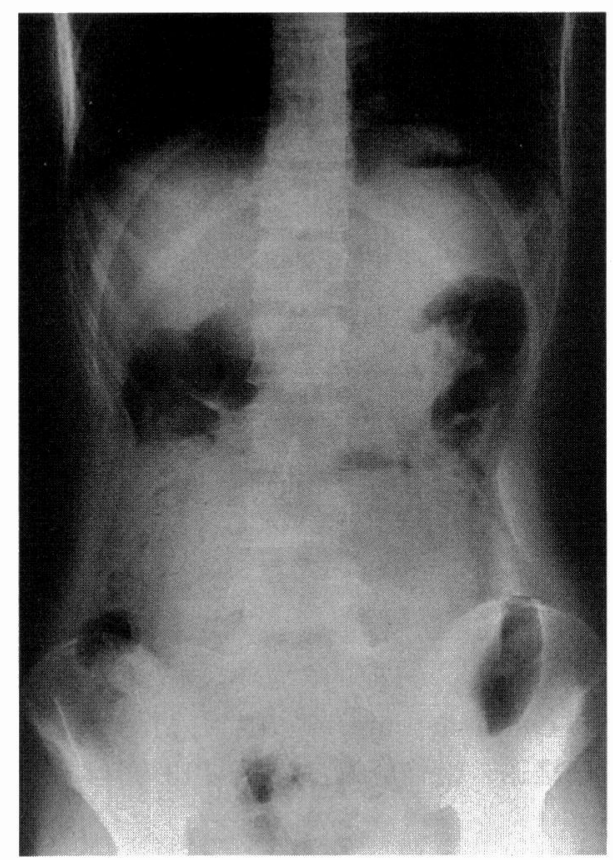

Fig. 2 Abdominal X-ray 14 hours after admission shows a small niveau in the left mid-abdomen.

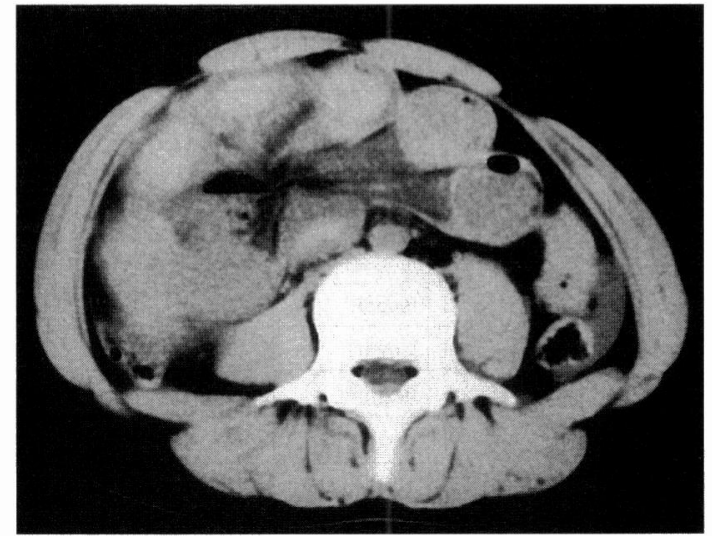

Fig. 3 Computed tomography demonstrats a "whirl sign" of the small intestine loops around the superior mesenteric artery. Ascites is also shown.

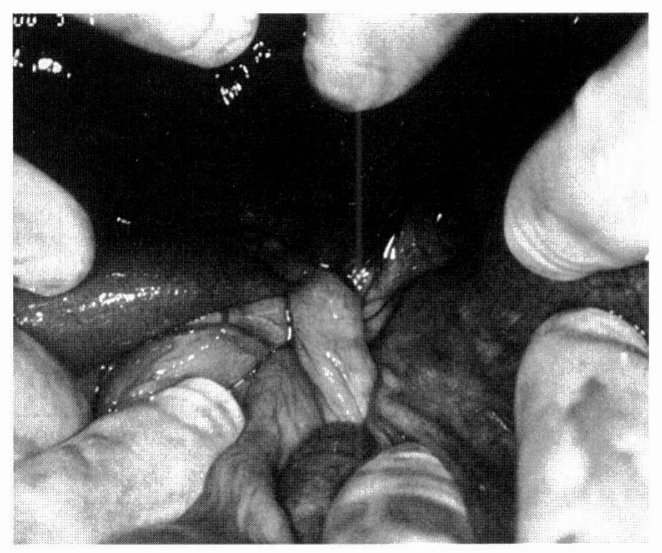

Fig. 4 The gangrenous small bowel 1s rotated around the mesentery by 360 clockwise rotation.

腹部にまで及ぶようになったが側臥位にしている と痛みは軽減されていた。しかしながら翌朝には 痛みは増強し腹部全体に広がり緊満状態となっ た。CPKは，1,571IU/Lに上昇した。腹部単純X線 検査では，左下腹部に小さな小腸二ボー像の出現 を疑わせた $($ Fig. 2$)$ 。来院後初めてCTを施行した ところ, 腸間膜動脈周囲を小腸が渦巻き状に巻き 込む “whirl sign” と腹水貯留を認めた (Fig. 3$)$ 。 以上の所見より小腸軸捻転症と診断し, 入院 15.5 時間後に緊急手術を施行した。腹部超音波検查

(US) は施行されなかった。手術室入室後より突 然低血圧と頻脈を呈しショック状態に陥ったた 
Table 1 Reported cases of primary small bowel volvulus in adults in Japan

\begin{tabular}{|c|c|c|c|c|c|c|c|c|c|}
\hline & author & year & age & sex & $\begin{array}{l}\text { shock } \\
\text { status }\end{array}$ & $\begin{array}{l}\text { hours from } \\
\text { admission to } \\
\text { operation }\end{array}$ & rotation & $\begin{array}{c}\text { gangrenous } \\
\text { small } \\
\text { intestine }\end{array}$ & prognosis \\
\hline 1 & Isogai ${ }^{8)}$ & 1979 & $*$ & * & $*$ & $*$ & $*$ & $*$ & alive \\
\hline 2 & Isogai ${ }^{\text {s) }}$ & 1979 & * & * & $*$ & $*$ & * & $*$ & alive \\
\hline 3 & Isogai ${ }^{8)}$ & 1979 & 52 & $\mathrm{M}$ & $(-)$ & $*$ & 180 & $(+)$ & alive \\
\hline 4 & Isogai ${ }^{8)}$ & 1979 & 69 & $\mathrm{M}$ & $(+)$ & $*$ & 720 & $(+)$ & $\dagger$ \\
\hline 5 & Isogai $^{8)}$ & 1979 & 71 & $\mathrm{~F}$ & $(+)$ & $*$ & 180 & $(+)$ & $\dagger$ \\
\hline 6 & Isogai ${ }^{8)}$ & 1979 & 66 & $\mathrm{M}$ & $(+)$ & * & 180 & $(+)$ & $t$ \\
\hline 7 & Tomita $^{9}$ & 1980 & 26 & $\mathrm{M}$ & $(-)$ & $*$ & 360 & $(+)$ & alive \\
\hline 8 & Tanabe $^{10)}$ & 1988 & 54 & $\mathrm{M}$ & $(+)$ & $*$ & 360 & $(+)$ & alive \\
\hline 9 & Kanou $^{11)}$ & 1988 & 73 & $\mathrm{~F}$ & $(+)$ & 52 & 360 & $(+)$ & $\dagger$ \\
\hline 10 & Kanzaki $^{12)}$ & 1988 & 59 & $\mathrm{M}$ & $(-)$ & $*$ & 720 & $(+)$ & alive \\
\hline 11 & Nomura $^{13)}$ & 1991 & 67 & $\mathrm{M}$ & $(-)$ & * & 180 & $(+)$ & alive \\
\hline 12 & Matsuo $^{14)}$ & 1991 & 58 & $\mathrm{~F}$ & $(+)$ & 11 & 360 & $(+)$ & $t$ \\
\hline 13 & Mizutani $^{15 \text { ) }}$ & 1991 & 61 & $\mathrm{M}$ & $(-)$ & $*$ & 360 & $(+)$ & alive \\
\hline 14 & Funayama $^{16)}$ & 1994 & 69 & $\mathrm{M}$ & $(-)$ & $*$ & 360 & $(+)$ & alive \\
\hline 15 & Murakami $^{17)}$ & 1996 & 26 & $\mathrm{M}$ & $(-)$ & 3 & 900 & $(-)$ & alive \\
\hline 16 & Matsuki ${ }^{18)}$ & 1997 & 50 & $\mathrm{~F}$ & $(-)$ & $*$ & * & $(+)$ & $*$ \\
\hline 17 & Matsuki $^{18)}$ & 1997 & 62 & $\mathrm{~F}$ & $(-)$ & $*$ & $*$ & $(+)$ & $*$ \\
\hline 18 & Shirahata ${ }^{19)}$ & 1997 & 24 & $F$ & $(-)$ & 10 & 360 & $(+)$ & + \\
\hline 19 & Takeshima $^{20)}$ & 1998 & 41 & $\mathbf{M}$ & $(-)$ & 5 & 360 & $(+)$ & alive \\
\hline 20 & Kudo $^{211}$ & 1998 & 71 & $\mathrm{~F}$ & $(-)$ & $*$ & 900 & $(+)$ & alive \\
\hline 21 & $\mathrm{Kaji}^{22)}$ & 1999 & 31 & $F$ & $(-)$ & * & 540 & $*$ & alive \\
\hline 22 & Kataoka $^{23)}$ & 1999 & 87 & $\mathrm{M}$ & $(-)$ & $*$ & 900 & $(-)$ & alive \\
\hline 23 & Kanda $^{24)}$ & 2000 & 73 & $F$ & $(-)$ & $*$ & 720 & $(-)$ & alive \\
\hline 24 & Matsuzawa $^{25)}$ & 2000 & 85 & $\mathrm{~F}$ & $(-)$ & $*$ & 360 & $(+)$ & alive \\
\hline 25 & Matsuzawa $^{25)}$ & 2000 & 92 & $\mathrm{~F}$ & $(-)$ & * & 360 & $(+)$ & alive \\
\hline 26 & Higa $^{26)}$ & 2000 & 64 & $\mathrm{M}$ & $(-)$ & * & 360 & $(-)$ & alive \\
\hline 27 & Sakaguchi $^{27)}$ & 2000 & 52 & $\mathrm{~F}$ & $(-)$ & $*$ & 360 & $(+)$ & $*$ \\
\hline 28 & Shimizu $^{28)}$ & 2000 & 29 & $\mathrm{~F}$ & $(-)$ & 7 & 360 & $(-)$ & alive \\
\hline 29 & Ito $^{29)}$ & 2000 & 58 & $\mathrm{M}$ & $(+)$ & $*$ & 720 & $(+)$ & alive \\
\hline 30 & Inafuku $^{30)}$ & 2000 & 63 & $\mathrm{M}$ & $(-)$ & 2 & * & $(-)$ & alive \\
\hline 31 & Watase & 2002 & 17 & $F$ & $(+)$ & 15.5 & 360 & $(+)$ & alive \\
\hline
\end{tabular}

め, serine protease inhibitor投与を開始した。

手術所見：上下腹部正中切開にて開腹したとこ ろ, 大量の血性腹水を認め, Treitz靶帯の $90 \mathrm{~cm}$ 肛 門側より $200 \mathrm{~cm}$ の小腸が上腸間膜動脈を中心に時 計方向に 360 度捻転し壊死に陥っていた (Fig. 4)。 それ以外には, 腹腔内には先天的な腸回転異常症, 癒着, ヘルニアなどの異常所見は認められなかっ たため成人原発性小腸軸捻転症と診断した。壊死
小腸を切除し，一期的に器械による functional end to end anastomosisを施行し閉腹した。

術後経過：術後経過は良好で13病日に退院し た。

\section{考察}

成人原発性小腸軸捻転症は先天的な腸回転異常 症や既往の手術による癒着などのない小腸の軸捻 
転を示しており極めて少ない疾患である1”。中近 東, 東南アジア，アフリカなどの若い男性に比較 的多いとされ5)，その原因は食生活の違いにより 小腸, 腸間膜が長いこと, 強い腹筋を持ち断食後 の過食や食後の激しい労働を行うことなどの生活 習慣の違いを挙げている。発症機転としては小腸 の腸管運動立進が重要であり, 本症例も夕食後で あったことからそのような機転も考えられる。成 人原発性小腸軸捻転症において腸管壊死を伴う場 合の死亡率は約 $50 \%$ と極めて高いと言われてい る3)。その原因は, 通常の機械的イレウスに認めら れる腹部膨満などの臨床所見, 血液所見異常がそ しく，腹部X線所見においては小腸鏡面像が認め られないものが多いなど6), 早期診断の困難性が 起因していると考えられた。成人原発性小腸軸捻 転症の早期診断には, 腸間膜血管を中心に小腸が 渦巻き状に腫瘤を形成する “whirl sign”が特徵的 でCT ${ }^{4)}, \mathrm{US}^{7}$ などが有効と報告されている。本症 例では入院時より腹部所見, 腹部X線所見は乏し く, 白血球数, CPKの高值はあったもののCT検査 をして初めて手術の決断を下した。術前ショック 状態に陥ったが手術によりようやく救命しえたこ とは，四らずも本疾患の早期診断の困難さを証明 することとなった。

本邦において成人原発性小腸軸捻転症は本症例 を含めて31例の報告がある(Table 1)。男性15例, 女性14例（不詳 2 例）であり，年齢は 17 歳から 92 歳までで平均 56.8 歳で, 本症例の17歳は最年少で あった。予後の記載のある28例中 6 例が死亡して おり死亡率は $21 \%$ であった。手術前にショック状 態に陥った 8 例のうち 5 例が死亡しておりショッ クを伴った症例の死亡率は $63 \%$ と高かった。入院 より手術までにかかった時間は 2 時間から52時間 でそのうち 10 時間以上かかった 4 例中 3 例が死亡 しておりその中で本症例は唯一の生存例であっ た。本症例以外の 3 例は, 敗血症からDICに陷り術 後20時間後に死亡した73歳女性の 1 例, 術後DIC より多藏器不全に陥り第11病日に死亡した58歳女 性の 1 例, 長期中心静脈栄養より肝不全に陥り術 後約 1 年 6 力月目に死亡した 24 歳女性の 1 例であ った。本症例では術前よりの抗生剤投与にもかか わらず敗血症によると思われるショック状態に陥
つたがその直後より serine protease inhibitor投 与を開始できたことやショック状態から手術終了 までが約 1 時間（手術時間53分）と比較的短時間 で手術侵襲も最小限にとどめられたことなどが生 存し之た要因の一つと考えられる。腸間膜の回転 は360 900度で，360度回転が最も多かった。

原発性小腸軸捻転症の診断にはCT検査が極め て有効であったが，本疾患の存在を念頭に入れて 診療にあたることがより一層重要だと考えられ た。

\section{おわりに}

術前CTにて“whirl sign”を呈した成人原発性 小腸軸捻転症の 1 例を経験したので報告した。本 邦では31例目であり，極めて稀な疾患と考えられ る。

\section{参考文献}

1) Duke JH, Yar MS: Primary small bowel volvulus cause and management. Arch Surg 112 : 685-688, 1977

2）高木純人, 山口宗之, 竹内節夫他：小児原原発性 小腸軸捻転症の 5 例。 日臨外医会誌 $52: 1070-$ 1075, 1991

3) Roggo A, Ottinger LW:Acute small bowel volvulus in adults. Ann Surg 216 : 135-141, 1992

4) Jaramillo D, Raval B : CT diagnosis of primary small bowel volvulus. Am J Roentgenol 147 : 941-942, 1986

5) Vaez-Zadeh K, Duts W, Nowrooz-Zadeh M : Volvulus of the small intestine in adults. Ann Surg $169: 265-271,1969$

6) Juler GL, Stemmer EA, Connolly JE : Preoperative diagnosis of small bowel volvulus in adults. Am J Gastroenterol 56 : 235-247, 1972

7) Pracros JP, Sann L, Genin G, et al : Ultrasound diagnosis of midgut volvulus. Pediatr Radiol $22: 18-20,1992$

8）磯谷正敏, 北島正是, 田近徹也他：小腸捻転イレ ウス23例の検討. 外科 $41: 557-562,1979$

9）富田凉一, 本庄 宏, 水野敏彦他：成人にみられ た原発性小腸捻転症の 1 治験例. 日大医誌 $39 ： 79$ $-83,1980$ 
10）田辺 博, 渡辺 進, 木澤英実他：原発性小腸捻 転症による小腸広範囲切除の 1 治験例。 日静脈・ 経腸栄養研会誌 $10 ： 141-143 ， 1988$

11）加納隆之, 北村政次，岡本篤武他：成人小腸軸捻 転症 4 例の検討. 日臨外会誌 $49 ： 665-672 ， 1988$

12）神崎 博, 松本匡浩, 今 真人他：成人小腸軸捻 転症の 1 治験例. 日救急医会関東誌 $9: 216-218$, 1988

13）野村修一，松森秀之，岸 淳彦他：食道発声者に 生じた小腸軸捻転の 1 例。医療 $45 ： 83-85,1991$

14）松尾信昭，石倉宏恭，石原崇史他：成人原発性小 腸軸捻転症の 1 例. 日臨外会誌 $52 ： 134-136,1991$

15）水谷鄉一, 堀江 修, 櫻井与志彦他：成人の原発 性小腸軸捻転症の 1 例. 外科 $53: 562-564,1991$

16）船山裕士，佐々木 巌, 宮下英士他：術後異なる 部位に再発した成人原発性小腸軸捻転の 1 手術 例. 日消外会誌 $27 ： 1113-1116 ， 1994$

17）村上雅彦, 伊藤洋二, 荒瀬 勉他：特徵的なCT像 より早期診断しえた原発性小腸軸捻転症の 1 例. 日臨外会誌57：1952-1955，1996

18) Matsuki M, Narabayashi I, Inoue $Y$, et al : Two adult cases of primary small bowel volvulus: Usefulness of computed tomographic diagnosis. Radiat Med 15 : 181-183, 1997

19）白幡康弘，並木健二，安斎 実他：原発性小腸軸 捻転の 1 例. 消外 $20 ： 1277-1281 ， 1997$

20）竹島義隆，仲地広美智，奥島憲彦他：成人原発性 小腸軸捻転症の 1 例. 日腹部救急医会誌 $18: 1033$
$-1037,1998$

21）工藤 俊, 龟山仁一, 鈴木 晃他：成人原発性小 腸軸捻転症の 1 例. 日消外会誌 $31: 2104-2107$, 1998

22）加治正英, 経田 淳, 吉本勝博他：成人原発性小 腸軸捻転症の 1 例。日臨外会誌 $60 ： 1298-1301$, 1999

23）片岡 剛，内山 清，清水義博：段階的に生じた 900 度の原発性小腸軸捻転に対し壊死小腸切除に て救命できた 1 例. 日消外会誌 $32 ： 1889 ， 1999$

24）上田城久朗, 能丸真司, 永田夏織他：空腸稳室を ともなった原発性小腸軸捻転症の 1 例. 日消病会 誌 $97: 33-37,2000$

25）松澤克典，笹本信幸，松澤信五他：高齢者の原発 性小腸軸捻転症の 2 例. 日消外会誌 $33: 604,2000$

26）比嘉宇郎，砂川宏樹，豊見山 健他：腸切除を回 避し得た原発性小腸軸捻転症の 1 例. 日消外会誌 $33: 604,2000$

27）坂口晃行, 安川十郎, 大東雄一郎他：成人原発性 小腸軸捻転症の 1 例。日外科系連会誌 $25 ： 593$, 2000

28）清水智治, 谷 徹, 花澤一芳他：成人原発性小 腸軸捻転を腹腔鏡補助下に整復した 1 例. 日臨外 会誌 $61 ： 698,2000$

29）伊東俊秀, 若林已代次, 杉下雄為他：成人原発性 小腸軸捻転症の 1 例。日臨外会誌 $61: 631,2000$

30）稲福 斉, 盛島裕次, 兼城 衛他：成人原発性小 腸軸捻転症の 1 例。日臨外会誌 $61 ： 631,2000$ 